ENTREPRENEURSHIP AND SUSTAINABILITY ISSUES

ISSN 2345-0282 (online) http://jssidoi.org/jesi/

2020 Volume 8 Number 1 (September)

http://doi.org/10.9770/jesi.2020.8.1(19)
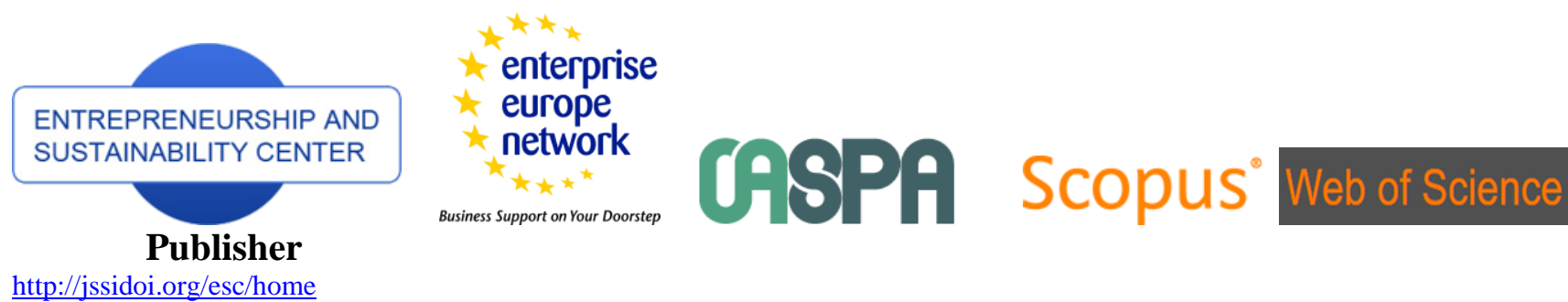

http://jssidoi.org/esc/home

\title{
SOCIAL ENTREPRENEURSHIP IN THE BALTIC AND NORDIC COUNTRIES. WOULD THE VARIETY OF EXISTING LEGAL FORMS DO MORE FOR THE IMPACT ON SUSTAINABLE DEVELOPMENT?
}

\author{
Tomas Lavišius ${ }^{1}$, Virginijus Bitė ${ }^{2}$, Mads Andenas ${ }^{3}$ \\ 1,2 Mykolas Romeris Law School, Mykolas Romeris University, Ateities st. 20, 08303 Vilnius, Lithuania \\ ${ }^{3}$ University of Oslo, Domus Media, Karl Johans gate, 470162 Oslo, Norway \\ E-mails: ${ }^{1}$ tolavisius@stud.mruni.eu; ${ }^{2}$ virginijus.bite@mruni.eu; ${ }^{3}$ mads.andenas@jus.uio.no
}

Received 20 March 2020; accepted 4 July 2020; published 30 September 2020

\begin{abstract}
Social enterprises have gained importance in European and national policies in recent years. There is a growing awareness that they create sustainable and inclusive growth and stimulate social innovation. Moreover, the question can be raised as to whether social entrepreneurship and, more precisely, legal forms available for social enterprises can make an impact on sustainable development. The United Nations 2030 Agenda for Sustainable Development, including its 17 Sustainable Development Goals (SDGs), is committed to eradicating poverty and achieving sustainable development worldwide by 2030. In the run-up to the adoption of the 2030 Agenda, the European Commission worked closely with the European Union (EU) Member States to ensure an ambitious global outcome. The European Commission committed to mainstreaming the SDGs into EU policies and initiatives. Amongst different tools for the implementation of SDGs, social entrepreneurship or social business can contribute to this process both nationally and internationally. The aim of this paper is to evaluate the current situation and capture best practice in the Baltic countries (Estonia, Latvia, and Lithuania) and the Nordic countries (Denmark, Finland, Iceland, Norway, and Sweden), through comparison of the legal forms available for social entrepreneurship or social business.
\end{abstract}

Keywords: social enterprise; social business; social entrepreneurship; soft law; social innovation; sustainable development goals.

Reference to this paper should be made as follows: Lavišius, T., Bite, V., Andenas, M. 2020. Social entrepreneurship in the Baltic and Nordic countries. Would the variety of existing legal forms do more for the impact on sustainable development? Entrepreneurship and Sustainability Issues, 276-290. http://doi.org/10.9770/jesi.2020.8.1(19)

JEL Classifications: K20, L31

Additional disciplines: law, economy, business

\section{Introduction}

Social enterprises have gained importance in European and national policies in recent years. There is a growing awareness that they create sustainable and inclusive growth and stimulate social innovation (GECES, 2016). By focusing on people as much as profit, they foster a sense of social cohesion and promote common well-being. To 


\section{ENTREPRENEURSHIP AND SUSTAINABILITY ISSUES}

ISSN 2345-0282 (online) http://jssidoi.org/jesi/

2020 Volume 8 Number 1 (September)

http://doi.org/10.9770/jesi.2020.8.1(19)

promote the social economy, we must develop an environment that facilitates access to funding, adequate legal framework, and awareness at both the national and local levels.

The 2030 Agenda for Sustainable Development, including its 17 sustainable development goals (SDGs), was adopted by Heads of State at a special United Nations (UN) Summit in 2015. The Agenda is a commitment to eradicate poverty and achieve sustainable development worldwide by 2030.

This article analyses the possible legal forms of social enterprise and their impact on the development of social entrepreneurship, as well as contributions to achieving the SDGs in particular countries. Legal forms suitable for social enterprise - such as foundations, associations, or limited companies - have developed over time in different directions in the different contexts of European Union (EU) Member States. In addition to the range of legal forms available to social enterprises, there is significant variation with respect to each legal form. Legal frameworks bring clarity by defining the nature, mission, and activities of social enterprises. In this research, the evaluation of different legal forms may be emphasized as one of the most important parts of the legal framework, because without sufficient legal identity enterprises cannot fully use their potential. Different organizations and researchers note that granting recognition and visibility to social enterprises through the creation of framework laws or the implementation of national strategies helps policymakers to target their support more effectively. Fostering the social economy requires the development of an environment that facilitates access to funding, adequate legal framework, and awareness at both the national and local levels.

The paper does not deal with the entire legal framework of social entrepreneurship (e.g. competition law, tax law, funding issues, etc.). This paper is based on comparative analysis of the legal forms as essential part of the framework for social entrepreneurship or social business in the Baltic and Nordic countries, in order to distinguish those main features and best practices of the legal regulation in this area that could help to achieve the SDGs.

Methodologically, this research focuses on the legislation of the EU and some recent initiatives that were undertaken by the Baltic and Nordic States to promote the development of social business through the development of new or adaptation of existing legal forms. The authors utilize qualitative research methods - such as the textual analysis method that has been used to examine the content and meaning of legal texts and other documents, as well as their structure. The scope of this research covers the EU legislation regulating this area and a comparative analysis of the legal regulation of social entrepreneurship in selected countries.

Scholars mostly approach the problems of social entrepreneurship through the lens of economics. J. Austin, J. Defourny, M. Nyssens, G. Lasprogata, M. Cotten, R. Martin, S. Osberg, and A. Nicholls could be mentioned as authors whose insights are valuable when looking into the conceptual development of the definition of social entrepreneurship.

Most of the scholars mentioned above consider that the definition of social entrepreneurship differs among the EU Member States. However, they also agree that social entrepreneurship plays an important role in society today and will continue to do so in the future. It will become an important tool to tackle social problems, especially those defined in the SDGs. Therefore, the justification of the concept of social entrepreneurship and the definition of its legal framework and regulatory characteristics remain important (e.g. Austin, Stevenson and Wei-Skillern, 2006).

\section{Legal status of social enterprise: the state of play}

Why are different legal forms of social enterprise important in seeking to implement SDGs? It was already stressed that social entrepreneurship could provide an additional space for using entrepreneurial methods where 


\section{ENTREPRENEURSHIP AND SUSTAINABILITY ISSUES}

ISSN 2345-0282 (online) http://jssidoi.org/jesi/

2020 Volume 8 Number 1 (September)

http://doi.org/10.9770/jesi.2020.8.1(19)

social needs could be more effectively met and tackled. The legal framework for social entrepreneurship is crucial in empowering them to act as SDG facilitators.

Legal frameworks play a fundamental part in any ecosystem of social entrepreneurship. They can help to make it relatively straight-forward to start-up and grow a social enterprise, and raise the visibility of this way of doing business. On the other hand, they can also hold people back by forcing entrepreneurs to spend time and effort looking for ways around barriers imposed by the legal system (ESELA, 2015). Legal regulation and measures tackling different social problems do not always come hand in hand. Therefore, it is important to evaluate the state of play in this field by assessing whether current legal regulation on legal forms for social entrepreneurship responds to SDGs in the countries under study.

The European Commission (EC) defines a social enterprise as an operator in the social economy whose main objective is to have a social impact rather than to make a profit for its owners or shareholders, and which operates by providing goods and services for the market in an entrepreneurial and innovative fashion and uses its profits primarily to achieve social objectives. A social enterprise is managed in an open and responsible manner and involves employees, consumers, and stakeholders affected by its commercial activities (European Commission [EC], 2011). It should be noted that the EC Communication on Social Business Initiative (SBI) does not emphasize any specific form of legal entity as a social enterprise.

The Organisation for Economic Cooperation and Development (OECD) notices that by granting recognition and visibility to social enterprises through the creation of framework laws or the implementation of national strategies, policy makers target their support more effectively (OECD/EU, 2017).

Antonio Fici stresses that the law - and, in particular, organizational law — is necessary to establish, preserve, convey, and disseminate the distinct identity of an organizational model that is primarily, though not exclusively, based on a specific purpose (as is the case with social enterprises). In this instance, organizational law performs a necessary and otherwise irreplaceable identifying function (Fici, 2015).

As will be seen from the examples analysed in this article, every legal form - such as a foundation, association, or limited company - has developed in different directions. In addition to a range of legal forms available to social enterprises, there is significant variation with respect to and within each legal form. Scientists from the European Social Enterprise Law Association (ESELA; from November 2018 - "Esela - The Legal Network for Social Impact") note that even when looking solely at a single legal form in a single state, there can be a wide variation as to the way the constitution of the legal form is drafted (ESELA, 2015). For example, with respect to a variety of social purposes which might be pursued, other aspects also might diverge (which stakeholders have an influence with respect to governance and decision-making and the way that profits are distributed, etc.). ESELA (2015) also notes that it is quite common in most countries to use different legal forms by adapting them specifically for use by a social enterprise. The most common scenario is to specify a social purpose for the enterprise and limit possibilities to distribute profits and surplus assets. This is not always possible, however, and, even where possible, it is also often feasible to remove or change such adaptations.

ESELA has identified three main types of legal forms used by social enterprises, namely: non-profit organizations; co-operatives; and share companies. Practically, there can be other legal forms (e.g. partnership, mutual organization, or mutual society, etc.) which are quite widespread, but only in certain countries. All these types of companies have common feature of hybridity balancing between social mission and traditional business approaches. It must be mentioned that one of the main aspects of research in this area is the transformation of traditional corporate law, introducing new hybrid legal forms of entities. Classical corporate law conception becomes more flexible and - in the case of social business legal regulation - falls into area of social law. This 


\section{ENTREPRENEURSHIP AND SUSTAINABILITY ISSUES}

ISSN 2345-0282 (online) http://jssidoi.org/jesi/

2020 Volume 8 Number 1 (September)

http://doi.org/10.9770/jesi.2020.8.1(19)

process leads to formation of new hybrid legal forms of businesses that are regulated not only by the principles of corporate but also social law and other branches of law.

In April 2013, the EC launched a social enterprise mapping study entitled "A Map of Social Enterprises and Their Eco-Systems in Europe" (hereafter - Mapping Study), as a follow-up to its 2011 Communication on the SBI. The Study concluded that insufficient legal recognition of social businesses in many countries made it difficult for policy makers to design and target specialist support for such businesses (e.g. fiscal incentives). Another problem is the so-called "narrow" understanding of the concept of a social enterprise. In some countries, like Finland or Lithuania, dedicated laws on social enterprise focus only on work integration social enterprises (WISE) and not on the SBI concept of a social enterprise, which is a much wider concept in all cases (ESELA, 2015, pp. 11-29).

It was mentioned that the concept of a Social Enterprise is interpreted differently in various EU Member States. Different Member States make available different legal forms for social enterprises. Moreover, the legal forms most used by social enterprises diverge greatly. The study of ESELA demonstrated that some social enterprises would benefit from some other legal status, such as a non-profit tax status or a WISE (ESELA, 2015, p. 32).

Summarising the definition of social enterprise provided in the SBI, we could say that the operational definition of social enterprise consists of three dimensions: an entrepreneurial dimension; a social dimension; and a dimension related to governance structure. Provided that the pursuit of explicit social aims is prioritised through economic activities, these three dimensions can interact in different ways, and their balanced combination matters most when identifying the boundaries of the social enterprise.

Therefore, there is no single model but rather many different models of social enterprise. This includes models that favour democratic and inclusive legal forms and business approaches, and those that include more managerial legal forms and business approaches. In the latter, the managers exercise control and seek independently to solve social problems. The EC (2015, p. 61) stresses that the legal recognition of social enterprises is an essential condition for developing the sector, arguing that legal forms or statuses recognize the specificity of social enterprises and contribute to giving them a clear, precise, and easy-to-convey identity, and clearly set the boundaries between social enterprises and other concepts (e.g. Corporate Social Responsibility). Moreover, it is the case in a lot of countries that legally recognized social enterprises are eligible for different tax exemptions, often involving some sort of corporation tax relief, relief from local or municipal taxes, etc. However, the legal status and recognition of social enterprise varies from state to state, therefore it is useful to analyse different examples of legal regulation to identify the best practices.

\section{Legal status of social enterprise in the Nordic and Baltic countries}

Different legal forms of social enterprise can be important for seeking to implement SDGs in every country. They can provide spaces for entrepreneurial methods to meet social needs. The main legal forms that can be used by social enterprises in the Nordic and Baltic countries will be explored here to evaluate the actual conditions in the countries researched. The SDGs cover such areas as: health, education, equality, employment, environment, and others. Traditionally and historically, most of those areas are, alongside other political measures, tackled by social enterprise, especially in those countries where social entrepreneurship is more advanced.

Here we make a comparative analysis of legal forms used by social enterprises in the Nordic and Baltic countries. As a preliminary remark, all of the countries mentioned have developed some legal statuses for social enterprise. However, not all of them have a special legal framework dedicated to social enterprise. Moreover, all of the countries have chosen not to create a dedicated legal form for social enterprise, but instead to establish a legal status which can be used by different legal entities. Despite the similarity mentioned across different countries, there are different approaches to status and the definition of a social enterprise. 


\section{ENTREPRENEURSHIP AND SUSTAINABILITY ISSUES}

ISSN 2345-0282 (online) http://jssidoi.org/jesi/

2020 Volume 8 Number 1 (September)

http://doi.org/10.9770/jesi.2020.8.1(19)

Regarding the identification of legal forms, as mentioned above, in some countries, such as Finland or Lithuania, dedicated laws on social enterprises focus only on WISEs. WISEs are, in essence, companies that promote the employment of disadvantaged or disabled people. On the other hand, they have a social enterprise related legal status, which can be obtained by organizations established for social purposes and that undertake activities wider than just work integration. It is noteworthy that the concept of a WISE is understood as a legal status in some of the countries, while in others it is regarded as a legal form. Where WISEs have a dedicated legal status, theoretically, any legal form can be called an integration enterprise - it only must meet the criteria set out in the dedicated law.

In advance, we can mention that the long tradition of association, foundation, and cooperative movements has a significant impact on the development of the social enterprise sector. However, of all Nordic countries only Denmark has a law that regulates the status of social enterprises. The Law on Registered Social Enterprises (Folketinget, 2014) adopted in June 2014 defines a registration system for social enterprises. This legal status can provide social enterprises with the basis for a common identity. The registration system gives the possibility for enterprises that meet certain criteria in the field of their operation and transparency to publicly show their social aims to authorities, business partners, and other stakeholders, through the right to use the term registered social enterprise (RSV). To qualify for the RSV, the enterprise must have a social purpose as an important element of operating business and meet several special requirements in the field of management, as well as apply restrictions on the distribution of their profits (Startupsvar.dk, n.d.). If an enterprise does not comply with the requirements of the Law, the Danish Business Authority has the right to remove it from the register. Three main legal forms of undertaking that can obtain the status of RSV may be distinguished: association (forening), foundation (fonden), and company limited by shares (CLS; aktieselskab).

In all Nordic countries, an association is defined as a voluntary union of persons founded to achieve the goal set in the statutes of the organization. What is important for us is that the goals set out in the association's articles of association can have a reference to a social enterprise's social aim(s). The Danish Act on Commercial Foundations (Retsinformation, 2014) and the Danish Act on Foundations and Certain Associations (Retsinformation, 2012) regulate the legal form of a foundation. Both legal forms (foundation and association) are not exclusively dedicated to social enterprises. The other common legal form - CLS - is a form of company commonly used by for-profit organisations and regulated by the Danish Act on Public and Private Limited Companies (Retsinformation, 2019). A CLS in Denmark, as elsewhere, is typically created with commercial aims in order to distribute profits to its shareholders. However, a social enterprise has the option to use a CLS (whether public or private) as its legal form. The articles of association of a CLS can be written in a way that provides the features of a social enterprise (EC, 2014a, pp. 33-44).

The most used legal forms in Sweden that fit the social enterprise needs are economic association (ekonomisk förening), non-profit association (ideell förening), and limited company (aktiebolag, AB). An economic association in Sweden is understood as an association of people united to meet their common economic, social, and cultural goals and needs through a legal entity, owned and democratically controlled in cooperation. Economic associations, in most cases (including the activity of social enterprises), are created to achieve social value. The legal status of an economic association is regulated by the Law on Economic Associations (Lagen om ekonomiska föreningar; Riksdagen, 2018). The statutes of a non-profit association can also be used by the founders to establish the characteristics of a social enterprise and can include social purposes. This form is also not exclusively dedicated to social enterprises. Finally, a social enterprise can also (whether it is a WISE or another kind of social enterprise) use a private limited liability company as its legal form. The articles of association can have provisions regarding the characteristics of a social enterprise, and the Law on Limited Companies (Aktiebolagslagen) regulates this legal form. There are no restrictions on the distribution of profits unless the articles of association include such limits (Riksdagen, 2005). Additionally, we must stress that Sweden 


\section{ENTREPRENEURSHIP AND SUSTAINABILITY ISSUES}

ISSN 2345-0282 (online) http://jssidoi.org/jesi/

2020 Volume 8 Number 1 (September)

http://doi.org/10.9770/jesi.2020.8.1(19)

has a long history of not-for-profit organizations with societal aims. However, some research shows (e.g. Thomas, Persson, \& Hafen, 2014) that although the level of institutionalisation of the different legal forms of social enterprises in Sweden remains low, some social innovations are quite significant.

Among others, WISEs actually have a different status compared to other social enterprises, because the Swedish Government recognizes them officially. However, in Sweden WISEs do not represent a specific legal form and are therefore managed by the same laws as other enterprises of the relevant legal form (EC, 2014d, p. 5).

In Finland, the status of social enterprises is defined in the Act on Social Enterprises, indicating that they "produce goods and services for the market and try to make a profit, the same as any other business." According to the Act, the purpose of social enterprises is to create jobs, in particular for the disabled and long-term unemployed. A social enterprise is a registered trader who is entered in the register of social enterprises (Act No. 1351/2003; Finlex, 2003). Therefore, the Act defines that social enterprises can operate only in the field of work integration as a WISE. The above-mentioned status can be applied to different forms of legal entities: limited liability company (osakeyhtiö, LLC); cooperative (osuuskunta); and foundation (rahasto; EC, 2014c, pp. 47-52). Moreover, social entrepreneurs get the mark of certification (the Social Enterprise Mark) if they promote wellbeing, limit their distribution of profits, and offer transparency of their business operations (Association for Finnish Work, 2019).

In Norway, the sector of social entrepreneurship has its origins both in the voluntary and business sectors. It is true that in the Norwegian government's reporting on its compliance to the UN 2030 Agenda for Sustainable Development, there is no reference made to corporate forms or the subject of this paper. The only reference made to domestic corporate entities is the reporting requirements that apply to them. It was stated that "Norwegian companies are expected to exercise corporate social responsibility and the Government is maintaining its engagement to further develop international reporting requirements, which are transposed into national law" (United Nations SDG Knowledge Platform, 2016).

We must notice that there is no specific legal act regulating social enterprises in Norway. Social enterprises operate by choosing one of several suitable legal forms: private limited company (privat aksjeselskap) that has a special branch of non-profit limited company (ideelt aksjeselskap), association (forening), foundation (stiftelse), general partnership (ansvarlig selskap), limited liability partnerships (selskap med begrenset ansvar), or cooperative (samvirke). The most used legal form for social enterprise in Norway is the ideelt aksjeselskap (Lovdata.no, 2007) - a non-profit limited company (NOU, 2016, 21 Kapittel 12 Stiftelsesloven, pp. 47-48). Such companies provide in their statutes that their profits should go to a specific purpose and not, as normally, to the shareholders. The non-profit limited company is not a separate legal form, but is a special branch of a private limited company under the Limited Liability Companies Act 1997. Voluntary associations are the second largest group of social enterprises. However, data from EC country fiche (European Commission, 2019b) shows that many initiatives of social entrepreneurship choose to operate as sole proprietorships which, according to the EC definition, fall into a "grey area" of the social enterprise sector.

In Iceland, historical research showed that civil society was a great contributor to social innovation and social entrepreneurship. Today this is still the case, however there is a noticeable tendency in that some of the older initiatives have grown into partially governmental organisations. Different social initiatives in Iceland closely cooperate with the public sector, and this can be considered as a favourable environment for the implementation of the SDGs. So far, social enterprises do not have specific legal regulation in the country. According to the EC country fiche (European Commission, 2019a, pp. 9-10), social enterprises in Iceland usually take one of the three following forms: association (félag), cooperative (samvinnufélaga), or self-governing foundation (sjálfstjórnandi grunnur). 


\section{ENTREPRENEURSHIP AND SUSTAINABILITY ISSUES}

ISSN 2345-0282 (online) http://jssidoi.org/jesi/ 2020 Volume 8 Number 1 (September) http://doi.org/10.9770/jesi.2020.8.1(19)

An association in this context would be defined as "an organised entity of a number of persons who unite or join together on a voluntary basis for some special non-profit purpose". There is no distinguished legal regulation of associations in Iceland. Cooperatives are founded based on cooperation, to seek mutual monetary benefit for cooperatives' members. Cooperatives operate in Iceland in accordance with regulation of the Co-operatives Act (Act No. 22/1991; Althingi, 1991). Moreover, some forms of cooperatives are regulated by special legislation: the Act on Housing Cooperatives (Act No. 66/2003; Althingi, 2003b) and the Act on Building Cooperatives (Act No. 153/1998; Althingi, 1998). However, not many social companies in Iceland operate as cooperatives. In addition, the elements of the operational definition of the social enterprise in Iceland can be found in the legislation on selfgoverning foundations (Act No. 19/1988; Althingi, 1998), legislation on cooperatives (Act No. 22/1991), legislation on Vocational Rehabilitation, and legislation on the Operation of Vocational Rehabilitation Funds (Act No. 60/2012). It was mentioned that there is no general law on associations, and yet the term association occurs 44 items in Icelandic legislation. According to the Act on the Registration of Enterprises (Act No. 17/2003; Althingi, 2003a), associations can be voluntarily registered in the public register of enterprises. Summarising, it can be stressed that organizations that can be considered as social enterprises are mostly registered as selfgoverning foundations and associations.

Some of the legal forms mentioned in the Nordic countries correlate with the implementation of SDG's more closely than others. It must be noted that not only legal forms of social enterprise determine correlation with SDG's. Other factors, such as different strategies and state policies, are also important. In Denmark, the role of social enterprise has so far been disconnected from the implementation of the SDGs. Although with the potential of the new legislation on social enterprise status, the country is on the right track. Denmark currently has an action plan as a framework for how the Danish government is working with the SDGs. Priorities are divided among growth, prosperity, environment, climate, and ensuring peaceful and safe communities. We see that social enterprises can work in all of these areas, especially in cooperation with government and local municipalities (Regeringen.dk, 2019). However, social enterprises have almost entirely been used as means of including people with some form of disadvantage or disability into the ordinary labour market - in businesses or projects with no attachment to public service delivery (Bruhn Lohmann, 2015).

The Swedish Government itself also works hard to achieve better results in the implementation of the SDGs. As the office of the Swedish Government announces, in 2020 the Government will submit a bill to the Riksdag setting out the overall direction for Sweden's work on implementing the 2030 Agenda nationally, at the EU level, and globally (Government Offices of Sweden, 2020). So far, the National Action Plan 2018-2020 is still intact (ESDN, 2020). The Government declares that with this Agenda it seeks to end poverty and hunger, realise the human rights of all, achieve gender equality and the empowerment of all women and girls, and ensure the lasting protection of the planet and its natural resources.

Regarding the correlation between the SDGs and the social enterprise sector in Finland, we think that the Finnish Social Enterprise Mark can become an instrument in helping to achieve such goals as: reduced inequalities or decent work and economic growth. Officially, Finland declares that it is one of the forerunners in the implementation of the 2030 Agenda. Finland developed a practical tool, called "Society's Commitment to Sustainability", through which the government gathers stakeholders from different fields to promote the goals of sustainable development.

In Norway at present, no specific legal form fits the concept of social enterprise on the full basis. The way Norway declares great political and public awareness about the SDGs, and its involvement in the implementation of these goals (e.g. United Nations SDG Knowledge Platform, 2016), can be potentially merged with a high level of social innovation and become a tool for the further development of the synergy between SDGs and social entrepreneurship. 


\section{ENTREPRENEURSHIP AND SUSTAINABILITY ISSUES}

ISSN 2345-0282 (online) http://jssidoi.org/jesi/

2020 Volume 8 Number 1 (September)

http://doi.org/10.9770/jesi.2020.8.1(19)

According to Iceland's voluntary national review on the implementation of the 2030 Agenda for Sustainable Development, the SDGs have been integrated into government policy on social, economic, and environmental affairs. Therefore, we can say that country's government understands the potential of different stakeholders to help in implementing SDGs. The government of Iceland declares that it seeks to identify and help marginalised groups in society, and to build partnerships with different stakeholders to address environmental issues. An interministerial working group leads the work of the Icelandic government towards implementing the SDGs. Also, the government builds public-private partnerships and thinks that the SDGs will not be met without the involvement of the private sector (Government of Iceland, 2019, p. 4).

The situation differs in the Baltic countries, although some similarities can also be identified. In Estonia, there are no legal forms that are created specifically for use by social enterprises. In addition, there are no official identification tools for social enterprises. This means that, although there are no specific regulations or pieces of legislation that restrict their establishment, there is also no legal form which can help with the establishment of social enterprises. The most common legal forms for social enterprises are associations (ühing) and foundations (sihtasutus). A social enterprise can also use a private limited company as its legal form. Under the Non-profit Associations Act (Riigiteataja, 2019a), an association can only use its profits to achieve the objectives specified in its articles of association, and it is not allowed to distribute profits among its members. The legal form of foundation - under the Foundations Act (Riigiteataja, 2018) - is also not allowed to distribute its profit to its members, and can use its income only to achieve the goals specified in its articles of association. The third legal form - regulated by the Commercial Code (Riigiteataja, 2019b) - is a limited company, that is usually used by for-profit organizations. However, a social enterprise still has the possibility to use a private limited company as its legal form. In such a case, the articles of association should provide the clear features of a social enterprise, as well as the social goals and provisions regarding limitations on the distribution of profits to shareholders (EC, 2014b, pp. 22-28).

It is worth mentioning that, despite the limited legal recognition at the level of self-regulation, the social enterprise community of Estonia enjoys quite active advocacy from the Estonian Social Enterprise Network. In addition, several soft-law tools, such as "Social Impact Measurement Tools for Young Social Entrepreneurs", are available (Know Your Impact, 2017).

We can therefore conclude that Estonia is one of two Baltic countries (alongside Lithuania) that have not developed a concrete legal framework for social entrepreneurship. However, it must be mentioned that the sector has been actively developing for several decades. Since there is no special legal structure for social enterprises in Estonia, registering as a "non-profit" is the default option for social purpose initiatives there. More specifically, most of them are registered as so-called civil society organizations: either non-profit associations (governed by their members), or foundations (governed by a board; Network of Estonian Non-profit Organizations, 2018).

Latvia is the only Baltic state that has already developed a new legal framework for social entrepreneurship. The Latvian Law on Social Business (Likumi.lv, 2017) entered into force on 1 April 2018. The Law foresees that a social enterprise is a limited liability company (Sabiedrība ar ierobežotu atbildību) which, in accordance with the procedures laid down in this Law, has been granted the status of a social enterprise, and which conducts an economic activity that creates a positive social impact. This can be the provision of social services, the formation of an inclusive civil society, the promotion of education, support for science, protection and preservation of the environment, animal protection, ensuring cultural diversity, or a variety of other causes. The status of a social enterprise shall be granted to a limited liability company if the objectives defined in its articles of association conform to the purpose of the Law and a meeting of its shareholders has made the decision to acquire the status of a social enterprise. The profit of a social enterprise cannot be divided between the members, but is invested to achieve the objectives defined in the articles of association. Moreover, to acquire the status of a social enterprise the enterprise shall ensure conformity with one of the following requirements. The first option requires that a 


\section{ENTREPRENEURSHIP AND SUSTAINABILITY ISSUES}

ISSN 2345-0282 (online) http://jssidoi.org/jesi/

2020 Volume 8 Number 1 (September)

http://doi.org/10.9770/jesi.2020.8.1(19)

representative of the target group must be involved in the executive body or supervisory body of the enterprise. The second option requires that a representative of the target group, or a representative of an association or foundation representing the target group, or an expert of the specific field, has to be involved in the advisory body of the enterprise, if such a body has been established.

Separately, we must mention that WISEs constitute an important type of social enterprise in Latvia, although they represent only one type and one way in which social enterprises can operate. It is not obligatory for social enterprises to employ individuals at risk of social exclusion. They may also promote the accessibility and quality of education, environmental protection, cultural diversity, social and health care, etc. (EC, 2018, p. 11).

The Lithuanian Government is acting similarly to the Latvian government in developing the Draft Law on the Social Business (E-seimas, 2019). This way, the government seeks to define the criteria and forms of social business, as well as the support measures to boost the social economy. The Draft Law was preliminarily evaluated by the committees of Parliament but has not yet attained reading in the plenary. It defines that a social enterprise is a legal entity (small or medium-sized enterprise) which works towards a social aim. The social enterprise shall gain its income from commercial activities in the market. It can distribute only 20 percent of its profits to shareholders, and so a major part of its profits should be reinvested towards its social aim.

This means that any small or medium-sized enterprise can apply for the status of social enterprise if it sets out the above-mentioned goals in its articles of association. Technically, this can be limited company (bendrove; which already has the status of WISE or not), association (asociacija), foundation (fondas), or public establishment (viešoji istaiga). Under the Lithuanian legislation, three of the mentioned forms (association, foundation, and public establishment) can be considered as non-profit organizations.

Despite the initiatives foreseen in the Draft Law, it still must be negotiated and adopted by Parliament. The question remains, then: what is the relationship between the existing legal regulation of WISEs and the provisions foreseen in the Draft Law? Several years ago, Lithuania already adopted the Law on Social Enterprise, regulating only the legal status of WISEs (as it is in Finland). The Law in fact institutionalized WISEs, focusing on any type of enterprise that is set up to create employment for people who are severely disadvantaged in the labour market. A financial aid system for WISEs was then set up to sustain their competitiveness in the market. Following the implementation of the Law, newly created "social enterprises" were indeed criticized for taking advantage of the financial aid system by following the letter (i.e. hiring disadvantaged individuals) but not the spirit of the Law (i.e. creating social impact; OECD/EU, 2019, p. 26).

Baltic countries (as well as Nordic) also have strategies for helping to reach the SDGs. It can be stressed that the Estonian government is already implementing measures and taking actions in the fields of 17 SDGs with the help of the non-governmental sector (Government Office of Estonia, 2016). This is a good sign; however, there is a lack of information on the potential involvement of the social entrepreneurship sector in this field.

In Latvia, newly established social enterprises can receive benefits (e.g. section 8 of the Law on Social Business defines types of benefits available to social enterprises) in the form of several fiscal awards and many other benefits. However, so far it is difficult to say how this situation correlates with SDGs. As with other countries mentioned, Latvia has a Sustainable Development Strategy that outlines the sustainable development objectives. One quite recent review showed that Latvia's sustainable development challenges are mostly visible in such areas as development of an innovative and eco-efficient economy and reduction of income and opportunity inequality (United Nations SDG Knowledge Platform, 2018a). We can state that these problems can also be tackled by, alongside governmental measures, using the potential of social enterprise, especially bearing in mind new legislation on social business entities. 


\section{ENTREPRENEURSHIP AND SUSTAINABILITY ISSUES}

ISSN 2345-0282 (online) http://jssidoi.org/jesi/

2020 Volume 8 Number 1 (September)

http://doi.org/10.9770/jesi.2020.8.1(19)

It also must be stressed that the Lithuanian Draft Law on Social Business has a close relationship to the SDGs. Although it is not stressed in the Draft Law explicitly, the authors of the Draft Law distinguished an obligatory social aim that must be sought by the social enterprise. The Draft Law defines a variety of activities, from the integration of the disadvantaged to cultural activities or the protection of the environment, that closely correlate with the SDGs.

Now is too early to assess whether some legal innovations will be introduced in the process of establishing and maintaining social business entities, or whether they will correlate with the SDGs. In the Lithuanian report to the $\mathrm{UN}$, it is stressed that one of the main priorities is the development of an innovative economy and smart energy (United Nations SDG Knowledge Platform, 2018b). If the legal framework for social enterprise is implemented soon, it could significantly help with the implementation of the above-mentioned priorities by using social enterprises as partners of government and municipalities in different projects.

Concluding about variety of legal forms that can be used as some sort of social enterprise, it must be noted that all compared jurisdictions have developed legal forms suitable for social enterprises. Some of countries (like Denmark or Latvia) have legal framework that is directly dedicated to foster development of social enterprise sector as such. Other jurisdictions have developed different legal forms that can be used by the social enterprise, even if these forms are not directly developed for social entrepreneurship. In such cases, if countries only indirectly recognise social enterprise as such, their main characteristics still meet the criteria of mentioned dimensions of SBA (an entrepreneurial dimension, a social dimension, and a dimension related to governance structure).

All legal entities that act as social enterprise have their explicitly defined social mission, whether it is defined in entity's statute or is expressed in some other way. In this research, we can exclusively speak only about legal entities that meet above mentioned criteria and how they correlate with SDGs. The other part of social enterprise which fall into so called "grey" area of legal regulation, is so called quasi social enterprises or social enterprises acting in quasi markets (See: Mason, Roy, and Carey, 2019) that could be more detailed discussed in the future.

\section{The framework of the EU legislation}

As demonstrated in the examples analysed, the legal frameworks bring clarity by defining the nature, mission, and activities of social enterprises. By granting social enterprises recognition and visibility through the creation of framework laws or the implementation of national strategies, policy makers can target their support more effectively. The updated EC report on social enterprises and their eco-systems in Europe (OECD/EU, 2017, p. 17) illustrates the state and development of social enterprise, and pays attention to the findings of recent empirical and theoretical research on social enterprise at the international level.

The report shows that in the year 2016 social enterprises were still conceived in significantly different manners by national legislatures, policy strategies, academics, and social entrepreneurs. In addition, there is a tendency to mix two main approaches. The first approach aims to identify the key features of social enterprises. The second approach designates general entrepreneurial dynamics oriented towards social innovation and social impact, and addresses the issues of social entrepreneurship in general more than the issues of social enterprise. From a legal point of view, the EC states that legislation designed for social enterprises could succeed in boosting social enterprise replicability if discussion on new legislation was reinforced by a deep understanding of social enterprise dynamics.

As mentioned earlier, the EC defined the term social enterprise in its Communication on SBI, and refers not to concrete legal forms but to a variety of types of business for which the social or societal objective of the common good is the basis for the commercial activity. Those businesses provide social services and/or goods and services 


\section{ENTREPRENEURSHIP AND SUSTAINABILITY ISSUES}

ISSN 2345-0282 (online) http://jssidoi.org/jesi/

2020 Volume 8 Number 1 (September)

http://doi.org/10.9770/jesi.2020.8.1(19)

to vulnerable persons and/or businesses with a method of production of goods or services that has a social objective (EC, 2011).

From the legal perspective, the Communication is not legally binding. However, it became the basis for different stakeholders (including EU Member States) to follow this definition. Moreover, the EC itself used this definition in further documents, some of which are legally binding. For example, Directive 2014/24/EU of the European Parliament and of the Council of 26 February 2014 on Public Procurement (hereafter - Directive 2014/24/EU) is an important and legally binding document which sets public procurement rules for all Member States. Article 77 (1) of the Directive speaks about reserved contracts. Member States may provide that contracting authorities may reserve the right for organisations to participate in procedures for the award of public contracts exclusively for those regarding health, social, and cultural services. Whilst it is not stressed explicitly that these measures are aimed to better the achievement of SDGs, evaluating systematically this can be considered as one additional tool for implementation of SDGs EU-wide. An organisation referred to in paragraph 1 shall fulfil all of the following conditions: its objective is the pursuit of a public service mission; profits are reinvested with a view to achieving the organisation's objective; and the structures of management or ownership of the organisation performing the contract are based on employee ownership or participatory principles, or require the active participation of employees, users, or stakeholders. There are several other criteria defined in Article 77, but the most important ones are the three above-mentioned features of the organization, which match the criteria of social enterprise as defined in the Communication.

Moreover, Article 20 of Directive 2014/24/EU also speaks about reserved contracts. According to it, Member States may reserve the right to participate in public procurement procedures for sheltered workshops and economic operators whose main aim is the social and professional integration of disabled or disadvantaged persons, or may provide for such contracts to be performed in the context of sheltered employment programmes, provided that at least $30 \%$ of the employees of those workshops, economic operators, or programmes are disabled or disadvantaged workers. The comparison of the legislation in several Member States demonstrates that this Article directly refers to WISEs, which in most countries are the main forms of social enterprise.

Another legally binding document is Regulation (EU) No. 1296/2013 of the European Parliament and of the Council of 11 December 2013 on an EU Programme for Employment and Social Innovation. Article 2 of the Regulation defines social enterprise in the same way as the Communication does. Although the definition of the status of social enterprise is not the aim of this Regulation per se (it regulates financial support measures for different activities, including support for social enterprises), the recognition of social enterprise status for practical purposes is definitely an important aspect when strengthening its legal status.

These examples show that legally non-binding definition becomes legally binding and affects not only the supranational legislation of the EU but also, for the purposes of implementation of the above-mentioned documents, the legislation of the Member States. As already mentioned, measures of the EU are not explicitly aimed to better achievement of the SDGs, however EU goals and actions on the implementation of SDGs have, among others, a clear social dimension. The European Economic and Social Committee recently stressed this (EESC, 2019), also emphasizing that this initiative can be "beneficial to civil society as a whole, including businesses (large and small), workers, consumers, farmers, NGOs, and citizens of all ages". Therefore, there is further potential for social entrepreneurship in the global field of the implementation of SDGs.

\section{Conclusions}

The comparative research of the legal forms available for social enterprises in particular countries showed that Nordic and Baltic countries, despite significantly different experiences and historical backgrounds, have a lot in common when developing a legal environment for social entrepreneurship. All discussed countries pay some 


\section{ENTREPRENEURSHIP AND SUSTAINABILITY ISSUES}

ISSN 2345-0282 (online) http://jssidoi.org/jesi/ 2020 Volume 8 Number 1 (September) http://doi.org/10.9770/jesi.2020.8.1(19)

attention to development or adaptation of legal forms that can be used by social enterprises. The pattern of noninstitutionalization of the separate legal forms of social enterprise is common in all of the states discussed. Only several exceptions (e.g. Danish and Latvian legislation on the status of social enterprises) are relevant, however they are not dedicated tools for the implementation of the SDGs. Although through the research a clear correlation of legal forms with successful implementation of the SDGs did not emerge, indirectly, sufficient spectre of legal forms undoubtedly contributes to development of social entrepreneurship sector.

The examples discussed allow us to argue that every country analysed has the potential for social entrepreneurship that can be exploited in implementing the SDGs. As has been seen, all of the countries researched have some legal framework for the implementation of the SDGs and spectre of legal forms that can be used by social enterprise. Moreover, it is obvious that some of the countries have longer traditions of social entrepreneurship (particularly, Nordic countries). Some of them already use the potential of social entrepreneurship in different schemes of public-private partnership (e.g. Iceland). Different forms of publicprivate partnership and greater trust in the potential of social enterprises could lead to more successful implementation of the SDGs. However, this fact does not necessarily correlate with the legal framework in every country discussed, because the legal status of social enterprise varies from country to country. Therefore, constant attention to the development of social entrepreneurship must be paid at a political level.

Despite some similarities in the countries analysed, there are different approaches to the legal status and definition of social enterprise. Not all countries have a special legal form dedicated exclusively to social enterprise. Moreover, all of the countries researched have chosen not to create a dedicated legal form for social enterprise, but instead to establish legal status, which different legal entities can use. From the examples analysed, it became evident that legal and, in some cases, institutional frameworks bring clarity by defining the nature, mission, and activities of social enterprises. In addition, where concrete legal forms are available, this creates a favourable environment for different cooperation schemes (e.g. cooperation with government and local municipalities in Denmark) that can add value to the implementation of the SDGs.

EU goals and actions on implementation of SDGs have among others a clear social dimension. However, the legal framework does not stress explicitly that the EU's initiatives in the field of social entrepreneurship are aimed at better achievement of the SDGs. Nevertheless, evaluating systematically, the EU social enterprise policy can be considered to be one additional tool for the implementation of the SDGs EU-wide. EU legislation affects the legislation of the Member States, and legally non-binding definitions become legally binding (specifically when speaking about operational definition of social enterprise). However, discussion on new legislation can also be exploited more effectively in order to achieve SDGs.

\section{References}

Althingi. (1988). Act No. 19/1988 - Lög um sjóði og stofnanir sem starfa samkvcemt staðfestri skipulagsskrá. Retrieved from https://www.althingi.is/lagas/nuna/1988019.html

Althingi. (1991). Act No. 22/1991 - Lög um samvinnufélög. Retrieved from https://www.althingi.is/lagas/nuna/1991022.html

Althingi. (1998). Act No. 153/1998 - Lög um byggingarsamvinnufélög. Retrieved from https://www.althingi.is/altext/stjt/1998.153.html

Althingi. (2003a). Act No. 17/2003 - Lög um fyrirtcekjaskrá. Retrieved from https://www.althingi.is/altext/stjt/2003.017.html

Althingi. (2003b). Act No. 66/2003 - $\quad$ Housing Cooperatives Act. Retrieved from https://www.government.is/lisalib/getfile.aspx?itemid=86752054-626b-11e8-942c-005056bc530c 


\section{ENTREPRENEURSHIP AND SUSTAINABILITY ISSUES}

ISSN 2345-0282 (online) http://jssidoi.org/jesi/ 2020 Volume 8 Number 1 (September) http://doi.org/10.9770/jesi.2020.8.1(19)

Althingi. (2012). Act No. 60/2012 - Lög um atvinnutengda starfsendurhaefingu og starfsemi starfsendurhafingarsjóða. Retrieved from https://www.althingi.is/altext/stjt/2012.060.html

Austin, J., Stevenson, H., \& Wei-Skillern, J. (2006). Social and commercial entrepreneurship: Same, different, or both? Entrepreneurship Theory \& Practice, 30(1), 1-22. https://doi.org/10.1111\%2Fj.1540-6520.2006.00107.x

Association for Finnish Work. (2019). The Finnish social enterprise mark. Retrieved from https://suomalainentyo.fi/en/services/finnishsocial-enterprise/the-finnish-social-enterprise-mark/

Bruhn Lohmann, M. (2015). What's the future of social enterprise in Denmark and the UK? Social Innovation Community. Retrieved from https://www.siceurope.eu/network/social-economy/whats-future-social-enterprise-denmark-and-uk

Directive 2014/24/EU of the European Parliament and of the Council of 26 February 2014 on Public Procurement. OJ L 94/65.

E-seimas. (2019). Lietuvos Respublikos socialinio verslo plètros ịstatymo projektas. Retrieved from https://eseimas.lrs.lt/portal/legalAct/lt/TAP/1ec626406a6e11e99684a7f33a9827ac?jfwid=-1c703921t9

ESELA. (2015). Social enterprise in Europe. Developing legal systems which support social enterprise growth. Retrieved from https://esela.eu/wp-content/uploads/2015/11/legal mapping publication 051015 web.pdf

European Commission (EC). (2011). Communication from the Commission to the European Parliament, the Council, the European Economic and Social Committee and the Committee of the Regions. Social Business Initiative. Creating a favourable climate for social enterprises, key stakeholders in the social economy and innovation. COM (2011) 682 final. Retrieved from https://ec.europa.eu/transparency/regdoc/rep/1/2011/EN/1-2011-682-EN-F1-1.Pdf

European Commission. (2014a). A map of social enterprises and their eco-systems in Europe. Country report: Denmark. Retrieved from https://ec.europa.eu/social/BlobServlet?docId=13027\&langId=en

European Commission. (2014b). A map of social enterprises and their eco-systems in Europe. Country report: Estonia. Retrieved from https://ec.europa.eu/social/BlobServlet?docId=12993\&langId=en

European Commission. (2014c). A map of social enterprises and their eco-systems in Europe. Country report: Finland. Retrieved from https://ec.europa.eu/social/BlobServlet?docId=13102\&langId=en

European Commission. (2014d). A map of social enterprises and their eco-systems in Europe. Country report: Sweden. Retrieved from https://ec.europa.eu/social/BlobServlet?docId=13277\&langId=en

European Commission. (2015). A map of social enterprises and their eco-systems in Europe. Synthesis report. Retrieved from https://ec.europa.eu/social/BlobServlet?docId=12987\&langId=en

European Commission. (2018). A map of social enterprises and their eco-systems in Europe. Updated country report: Latvia. Retrieved from https://ec.europa.eu/social/BlobServlet?docId=20564\&langId=en

European Commission. (2019a). Social enterprises and their ecosystems in Europe. Country fiche: Iceland. Retrieved from https://op.europa.eu/s/n1mn

European Commission. (2019b). Social enterprises and their ecosystems in Europe. Country fiche: Norway. Retrieved from https://op.europa.eu/s/nZwC

European Economic and Social Committee (EESC). (2019). SDO work programme/roadmap 2018-2020. Retrieved from https://www.eesc.europa.eu/sections-other-bodies/observatories/sustainable-development-observatory

Expert Group on Social Entrepreneurship (GECES). (2016). Social enterprises and the social economy going forward, a call for action from the Commission. Retrieved from http://ec.europa.eu/growth/content/social-enterprises-and-social-economy-going-forward-0_en

European Sustainable Development Network. 2020. Single country profile: Sweden. Retrieved from https://www.sdnetwork.eu/?k=country $\% 20$ profiles \&s=single $\% 20$ country $\% 20$ profile \&country=Sweden\#sdg 


\section{ENTREPRENEURSHIP AND SUSTAINABILITY ISSUES}

ISSN 2345-0282 (online) http://jssidoi.org/jesi/ 2020 Volume 8 Number 1 (September) http://doi.org/10.9770/jesi.2020.8.1(19)

Fici, A. (2015). Recognition and legal forms of social enterprises in Europe: A critical analysis from a comparative law perspective. Euricse Working Papers 82(15). Retrieved from https://www.euricse.eu/wp-content/uploads/2015/12/WP-82 15 Fici2.pdf

Finlex. (2003). Act No. 1351/2003 on Social Enterprises. Retrieved from http://www.finlex.fi/en/laki/kaannokset/2003/en20031351.pdf.

Folketinget. (2014). L 148 Forslag til lov om registrerede socialøkonomiske virksomheder. Retrieved from https://www.ft.dk/samling/20131/lovforslag/1148/20131_1148_som_vedtaget.htm

Government Office of Estonia. (2016). Executive summary of the Estonian review on implementation of the Agenda 2030. Retrieved from https://www.riigikantselei.ee/sites/default/files/content-

editors/Failid/SA_eesti/2016_06_14_executive_summary_of_estonian_review_on_agenda2030_final.pdf

Government of Iceland. (2019). Iceland's implementation of the 2030 Agenda for sustainable development. Voluntary national review. Retrieved from https://sustainabledevelopment.un.org/content/documents/23408VNR_Iceland_2019_web_final.pdf

Government Offices of Sweden. (2020, February 21). Gabriel Wikström appointed national coordinator for the 2030 Agenda [Press release]. Retrieved from https://www.government.se/press-releases/2020/02/gabriel-wikstrom-appointed-national-coordinator-for-the2030-agenda/

Know Your Impact. (2017). Social impact measurement tools for young social entrepreneurs. Retrieved from https://knowyourimpact.ku.edu.tr/the-project/

Likumi.lv. (2017). Social Enterprise Law. Retrieved from https://likumi.lv/ta/en/en/id/294484-social-enterprise-law

Lovdata.no. (2001). Lov om stiftelser (stiftelsesloven). Retrieved from https://lovdata.no/dokument/NL/lov/2001-06-15-59

Lovdata.no. (2007). Lov om aksjeselskaper (aksjeloven). Retrieved from https://lovdata.no/dokument/NL/lov/1997-06-1344/KAPITTEL_2-1\#\%C2\%A72-2

Mason, C., Roy, M.J. and Carey, G. 2019). Social enterprises in quasi-markets: exploring the critical knowledge gaps, Social Enterprise Journal 15(3): 358-375. https://doi.org/10.1108/SEJ-09-2018-0061

Network of Estonian Non-profit Organizations. (2018). Estonian Civil Society. Retrieved from https://heakodanik.ee/en/civil-society/

Norges offentlige utredninger (NOU). (2016). 21 Forslag til ny stiftelseslov. Retrieved from https://lovdata.no/static/NOU/nou-2016-21.pdf

OECD/EU. (2017). Boosting Social Enterprise Development: Good Practice Compendium. Paris: OECD Publishing. https://doi.org/10.1787/9789264268500-en

OECD/EU. (2019). Boosting social entrepreneurship and social enterprise development in Lithuania: In-depth policy review. OECD Local Economic and Employment Development (LEED) Papers, No. 2019/02. Paris: OECD Publishing. https://doi.org/10.1787/502fc6ef-en

Regeringen.dk. (2019). Handlingsplan for FN’s 17 verdensmål. Retrieved from https://www.regeringen.dk/publikationer-ogaftaletekster/handlingsplan-for-fns-verdensmaal/

Regulation (EU) No. 1296/2013 of the European Parliament and of the Council of 11 December 2013 on a European Union Programme for Employment and Social Innovation and amending Decision No. 283/2010/EU establishing a European Progress Microfinance Facility for employment and social inclusion. OJ L 347/238.

Retsinformation. (2012). Bekendtgørelse af lov om fonde og visse foreninger [Danish Act on Foundations and Certain Associations]. Retrieved from https://www.retsinformation.dk/forms/r0710.aspx?id=138731

Retsinformation. (2014). Lov om erhvervsdrivende fonde [The Danish Act on Commercial Foundations]. Retrieved from https://www.retsinformation.dk/forms/r0710.aspx?id=163656

Retsinformation. (2019). Bekendtgørelse af lov om aktie- og anpartsselskaber (selskabsloven) [The Danish Act on Public and Private Limited Companies]. Retrieved from https://www.retsinformation.dk/Forms/R0710.aspx?id=209846 


\section{ENTREPRENEURSHIP AND SUSTAINABILITY ISSUES}

ISSN 2345-0282 (online) http://jssidoi.org/jesi/ 2020 Volume 8 Number 1 (September) http://doi.org/10.9770/jesi.2020.8.1(19)

Riigiteataja. (2018). Foundations Act. Retrieved from https://www.riigiteataja.ee/en/eli/ee/529012015010/consolide/current

Riigiteataja. (2019a). Non-profit Associations Act. Retrieved from https://www.riigiteataja.ee/en/eli/ee/520062017014/consolide/current

Riigiteataja. (2019b). Commercial Code. Retrieved from https://www.riigiteataja.ee/en/eli/ee/522062017003/consolide/current

Riksdagen. (2005). Aktiebolagslag (2005:551). Retrieved from https://www.riksdagen.se/sv/dokument-lagar/dokument/svenskforfattningssamling/aktiebolagslag-2005551_sfs-2005-551

Riksdagen. (2018). Lag (2018:672) om ekonomiska föreningar. Retrieved from https://www.riksdagen.se/sv/dokumentlagar/dokument/svensk-forfattningssamling/lag-2018672-om-ekonomiska-foreningar_sfs-2018-672

Startupsvar.dk. (n.d.). Registreret socialøkonomisk virksomhed - RSV. Retrieved from https://www.startupsvar.dk/registreret-socialvirksomhed

Thomas, H., Persson, R., \& Hafen, N. (2014). Social enterprise, social innovation and social entrepreneurship in Sweden: A national Retrieved

from

https://sofisam.se/download/18.72b312e7163120a87495d6d6/1525433671511/EFESEIIS\%20National\%20Report\%20Sweden.pdf

United Nations SDG Knowledge Platform. (2016). Norway: Initial steps towards the implementation of the 2030 agenda. Voluntary national review. Retrieved from https://sustainabledevelopment.un.org/memberstates/norway

United Nations SDG Knowledge Platform. (2018a). Latvia: Main messages. Voluntary national review. Retrieved from https://sustainabledevelopment.un.org/memberstates/latvia

United Nations SDG Knowledge Platform. (2018b). Lithuania: Main messages. Voluntary national review. Retrieved from https://sustainabledevelopment.un.org/memberstates/lithuania

Mads ANDENAS holds a $\mathrm{PhD}$ in law and is currently a professor of law at the Faculty of Law, University of Oslo, and Institute of Legal Studies, University of London. He has held senior academic appointments in the United Kingdom, including as Director of the British Institute of International and Comparative Law, London, and Director of the Centre of European Law at King's College, University of London. He is involved in research in the fields of international, EU and comparative law, and European and domestic private and regulatory law.

ORCID ID: orcid.org/0000-0002-4411-4427

Virginijus BITÉ holds a PhD in law and is currently a professor of Company Law and Director of the Institute of Private Law at the Law School of Mykolas Romeris University, Lithuania. He is also an academic member of European Corporate Governance Institute (ECGI) and a member of the editorial board of research journal Jurispudencija (MRU). His research interests include corporate and commercial law, entrepreneurship.

ORCID ID: orcid.org/0000-0003-3902-0175

Tomas LAVIŠIUS is a PhD student at the Institute of Private Law, Law School of Mykolas Romeris University, Lithuania. His research interests include legal regulation of social entrepreneurship, legal forms of social enterprise in the EU and EU Member States. He published several articles on the topic and constantly delivers presentations in international conferences. He is also a member of Lithuania's Council of Sustainability Experts convened by Lithuania's Responsible Business Association (LAVA).

ORCID ID: orcid.org/0000-0002-1788-600X

Make your research more visible, join the Twitter account of ENTREPRENEURSHIP AND SUSTAINABILITY ISSUES: @Entrepr69728810

Copyright (C) 2020 by author(s) and VsI Entrepreneurship and Sustainability Center

This work is licensed under the Creative Commons Attribution International License (CC BY).

http://creativecommons.org/licenses/by/4.0/

C) $\underset{\mathrm{EY}}{\mathrm{BP}}$ Open Access 